\section{International Scientific Journal Theoretical \& Applied Science}

p-ISSN: 2308-4944 (print) e-ISSN: 2409-0085 (online)

Year: $2017 \quad$ Issue: $12 \quad$ Volume: 56

Published: 19.12.2017 $\quad \underline{\text { http://T-Science.org }}$

SECTION 11. Biology. Ecology. Veterinary.
Yao Kanga

Botanical Laboratory, Unit of Formation and Biosciences Research,

Félix HOUPHOUËT-BOIGNY University. PO Box, 582, Abidjan 22 - Côte d'Ivoire. kanga.yao@yahoo.fr

Nathalie Guessennd

Bactériology-Virology Laboratory, Unit of Antibiotics, the Natural Substances and the Monitoring of Resistances of the Micro-organisms to Anti-Infectious (ASSURMI), Pasteur Institute of Côte d'Ivoire, PO Box, 490, Abidjan 01 - Côte d'Ivoire.

Kouadio Bene

Botanical Laboratory, Unit of Formation and Biosciences Research, Félix HOUPHOUËT-BOIGNY University.

Adon Basile Yapi

Botanical Laboratory, Unit of Formation and Biosciences Research, Félix HOUPHOUËT-BOIGNY University.

Guédé Noel Zirihi

Botanical Laboratory, Unit of Formation and Biosciences Research, Félix HOUPHOUËT-BOIGNY University.

Dosso Mireille Bactériology-Virology Laboratory, Unit of Antibiotics, the Natural Substances and the Monitoring of Resistances of the Micro-organisms to Anti-Infectious (ASSURMI), Pasteur Institute of Côte d'Ivoire

\title{
BOTANICAL STUDY AND EVALUATION OF THE IN VITRO ANTIBACTERIAL ACTIVITY OF 70\% ETHANOLIC EXTRACT OF PIPTADENIASTRUM AFRICANUM HOOK (FABACEAE) ON STAPHYLOCOCCUS AUREUS ISOLATED FROM URINE
}

\footnotetext{
Abstract: Objective: To know the antimicrobial medicinal plants of the Haut-Sassandra region (in the west center of Côte d'Ivoire) and to evaluate the antibacterial activity of the most requested species. Methods and results: An ethnobotanical survey conducted in the Haut-Sassandra Region using questionnaires allowed to gather information on the therapeutic uses of antimicrobial plants in the Region. It allowed to make a list of 58 species of plants. The taxon Piptadeniastrum africanum Hook (Fabaceae) is most in demand. The method of double dilution in the liquid and solid medium was used for the evaluation of the antibacterial activity of the extracts of the stem bark of this plant. The MBC / MIC ratio ranges from 1 to $2.25 \mathrm{mg} / \mathrm{mL}$. The ethanolic extract (EE70 \%) of the stem bark possesses bactericidal activity on all the tested strains of Staphylococcus aureus.

Conclusion: These results reveal that the Haut-Sassandra Region contains interesting antibacterial plants.

Key words: ethnobotany, antibacterial, $M I C, M B C$

Language: English

Citation: Kanga Y, Guessennd N, Bene K, Yapi AB, Zirihi GN, Mireille D (2017) BOTANICAL STUDY AND EVALUATION OF THE IN VITRO ANTIBACTERIAL ACTIVITY OF 70\% ETHANOLIC EXTRACT OF PIPTADENIASTRUM AFRICANUM HOOK (FABACEAE) ON STAPHYLOCOCCUS AUREUS ISOLATED FROM URINE.. ISJ Theoretical \& Applied Science, 12 (56): 13-18.
}

Soi: http://s-o-i.org/1.1/TAS-12-56-4 Doi: crossef https://dx.doi.org/10.15863/TAS.2017.12.56.4 


\section{INTRODUCTION}

The resistance of microorganisms against classical antibiotics poses a real public health problem. Faced with this situation there is a pressing need for constant renewal of active principles [1]. The molecules sought must have various other chemical properties and mechanisms of action against these pathogenic microbes [2]. Medicinal plants represent a significant source of new medicines; especially since they have indesirable effect [3]. It therefore becomes logical to continue or even to intensify research in this direction knowing that plants remain an almost inexhaustible source of biomolecules. In addition, special attention is being paid to drugs and products of natural origin [4]. It is estimated that $80 \%$ of the world's population depends mainly on traditional medicine for the treatment of diseases [5]. The dependence on remedies derived from indigenous plants is particularly marked in developing countries where Western medicine is often absent or simply too expensive. An ethnobotanical survey carried out in the Haut-Sassandra region of Cote d'Ivoire allowed us to select Piptadeniastrum africanum (Fabaceae), a plant used in the treatment of bacterial diseases in the traditional environment. The aim of this study is therefore to contribute to the valorisation of Côte d'Ivoire medicinal plants. It aims at evaluating the antibacterial activity of the ethanolic extract of the stem bark of Piptadeniastrum africanum on Staphylococcus aureus, germs that are often involved in urinary disorders.

\section{MATERIAL}

1.1. Vegetal material

The vegetal material used consists of the stem bark of Piptadeniastrum africanum harvested in the HautSassandra region of Côte d'Ivoire in August 2015, the identification of which was made by the National Floristic Center of Côte d'Ivoire.

1.2. Bacterial material

The bacterial material consists of a reference and five multi-resistant strains of Staphylococcus aureus and it is provided by the Laboratory of Bacteriology and Virology of the Institut Pasteur of Côte d'Ivoire.

\section{METHODS}

\subsection{Monographic study of Piptadeniastrum africanum}

To allow easy identification of this plant in a natural environment, a full monographic study was carried out; it took into account:

- the botanical family of the plant ;

- general information on this botanical family ;

- detailed description of the plant ;

- some traditional therapeutic uses in the West African Pharmacopoeia.

2.2. Preparation of extracts
The stem bark of Piptadeniastrum africanum harvested was rinsed with water and dried in the shelter of the sun. These dried plant organs were then reduced to a fine powder using an IKA-MAG RTC electric grinder. A gray powder is obtained. The extracts (total aqueous and ethanolic $70 \%$ ) were prepared according to the method described by [6].

Total aqueous extract: One hundred grams (100 g) of bark powder are homogenized in 1 liter of distilled water in a Blender (Mixer) of Life's Superb brand (LS-317) for three times three minutes at room temperature. The homogenate obtained is filtered successively on hydrophilic cotton and then on Wattman paper $(3 \mathrm{~mm})$. With an oven set at $50{ }^{\circ} \mathrm{C}$, the extraction solvent is eliminated. The dry evaporate is recovered in powder form which constitutes the total aqueous extract (TAE).

Ethanol / water partition: Ten grams $(10 \mathrm{~g})$ of the TAE are dissolved in $100 \mathrm{~mL}$ of a $70 \%$ ethanol solution and then homogenized in a Blender [7]. After decantation in a separatory phial, the supernatant is collected, filtered on cotton to remove any residue and dried in an oven $\left(50{ }^{\circ} \mathrm{C}\right.$.). The powder obtained constitutes the $70 \%$ ethanolic extract $(70 \% \mathrm{EE})$.

\subsection{Calculation of the yield}

The yield is the amount of extract obtained from the vegetable powder. It is expressed as a percentage. In practice, it is determined by the ratio of the weight of the dry extract after evaporation to the weight of the powder of dry plant material used for extraction multiplied by 100 . This results in the following formula: $\mathrm{Rd}=(\mathrm{mx} 100) / \mathrm{M}$. $(\mathrm{Rd}$ : extraction yield in percentage, $\mathrm{m}$ : mass in gram of the dry extract, $\mathrm{M}$ : mass in gram of the powder of the drug).

2.4. Sterility test of $70 \%$ ethanolic extract

The purpose of this test was to verify that the extract contained no bacteria or fungus. To do it, 0.1 $\mathrm{g}$ of this extract to be tested was placed in $10 \mathrm{ml}$ of thioglycholate broth and incubated at $37^{\circ} \mathrm{C}$ for 24 hours. After this time, the broth was seeded on a Petri dish containing the ordinary agar and another containing the Sabouraud agar and then incubated under the same conditions. The extract is declared sterile, if no colony is visible on the agar box [8].

2.5. Preparation of the bacterial inoculum

Two isolated colonies of 18 hours bacterial culture were homogenized in $10 \mathrm{~mL}$ of MullerHinton broth and incubated for 3 hours at $37^{\circ} \mathrm{C}$ for pre-culture. A $0.1 \mathrm{~mL}$ sample of the pre-culture broth was diluted in a tube containing $10 \mathrm{~mL}$ of MullerHinton broth. This bacterial suspension produced was the bacterial inoculum of dilution 100. Two isolated colonies of an 18 hours bacterial culture were homogenized in $10 \mathrm{~mL}$ of Muller-Hinton broth and incubated for 3 hours at $37{ }^{\circ} \mathrm{C}$ for pre-culture. A $0.1 \mathrm{~mL}$ sample of the pre-culture broth was diluted in a tube containing $10 \mathrm{~mL}$ of Muller-Hinton broth. 
This produced bacterial suspension was the bacterial inoculum of dilution 100.

2.6. Numeration of bacterial inoculum

The bacterial inoculum was diluted 10 to 10 fold untill $10^{-4}$ dilution. Four successive dilutions of $10^{-1}$ to $10^{-4}$ are obtained. The initial bacterial inoculum and the four successive dilutions were inoculated with a $2 \mu \mathrm{L}$ calibrated loop on MullerHinton agar plates with $5 \mathrm{~cm}$ long stripes constituting the A box.

2.7. Preparation of the concentration range of the substance

The concentration range was prepared in 16 test tubes numbered from $T_{1}$ to $T_{16}$ by the double-dilution method in liquid medium. This concentration range varies from $200 \mathrm{mg} / \mathrm{mL}$ to $0.006 \mathrm{mg} / \mathrm{mL}$. For this purpose, $10 \mathrm{~mL}$ of sterile distilled water were put in the $\mathrm{T}_{1}$ tube and $5 \mathrm{~mL}$ in all the other tubes. In the $\mathrm{T}_{1}$ tube, $2 \mathrm{~g}$ of plant extract were dissolved at a concentration of $200 \mathrm{mg} / \mathrm{mL}$. A $5 \mathrm{~mL}$ volume of the $\mathrm{T}_{1}$ tube was transferred into the $\mathrm{T}_{2}$ tube and then homogenized. This operation was repeated until tube $\mathrm{T}_{16}, 5 \mathrm{~mL}$ of tube $\mathrm{T}_{16}$ was rejected. The contents of the tubes were filtered on a membrane (MILLEX $\mathrm{GV} \otimes)$ of diameter $0.45 \mu \mathrm{m}$ and stored in a refrigerator at $4{ }^{\circ} \mathrm{C}$.

\subsection{Antibacterial testing}

The antibacterial tests were carried out using the dilution method into liquid medium $[9,10]$ in a series of 16 experimental tubes, a growth control tube and a control tube for the test of sterility. $1 \mathrm{~mL}$ of the extract of the highest concentration is transferred to the $T_{1}$ tube, the next concentration in the $T_{2}$ tube, and so on untill the lowest concentration in the $\mathrm{T}_{16}$ tube. This procedure ultimately resulted in the concentration of $T_{1}$ to $T_{16}$ being reduced from double to single, ie from $100 \mathrm{mg} / \mathrm{mL}$ to $0.003 \mathrm{mg} / \mathrm{mL}$. The sterility control tube receives $2 \mathrm{~mL}$ of MullerHinton broth. All of these tubes were incubated for 24 hours at $37^{\circ} \mathrm{C}$. This operation has been repeated 3 times in succession. Thereafter, the contents of the tubes in which no disturbance was observed was used to inoculate the Muller-Hinton agar on $5 \mathrm{~cm}$ striations starting with the first tube without turbidity and incubated at $37^{\circ} \mathrm{C}$ for 24 hours. Thus, the MIC was therefore the concentration of the first tube from which no disturbance to the naked eye was observed. After 24 hours of incubation at $37^{\circ} \mathrm{C}$, the minimum bactericidal concentration (MBC) was determined by comparing the density of the streaks with that of the previously prepared A box.

\section{RESULTS}

3.1. Monographic study of the plant

Piptadeniastrum africanum belongs to the family Fabaceae

* Family of Fabaceae

Fabaceae are one of the largest families of flowering plants, with more than 730 genera and
19400 species distributed in both temperate and tropical environments [11]. They are herbaceous plants, shrubs, trees or lianas. The family is cosmopolitan of cold and tropical areas. The leaves are generally alternate, pinnate or trifoliolate and stipulated. However, there are some evolutions.

According to [12] the Fabaceae can be divided into 3 subfamilies:

- the subfamily of Mimosoideae ;

- the subfamily Caesalpinoideae ;

- the subfamily Papilionoideae or Faboideae.

* Some therapeutic uses of Fabaceae

Currently, several molecules are used in therapeutics and are extracted from various species of Faboideae: spartéine, a ganglioplégique alkaloid used in cardiology and obstetrics, isolated from Cytisus scoparius L. Link, rutin, a flavonoid used in phlebology, isolated from Sophora japonica L. or physostigmine from Physostigma venenosum Balf. The latter is a reversible inhibitor of cholinesterases, used as an antidote by parasympatholytic intoxication and tested in the treatment of Alzheimer's disease [13].

* Description of the plant

Piptadenia africana or Piptadeniastrum africanum is a large tree. It is a leguminous plant of the subfamily of mimosoideae whose crown is more or less tabular. I can reach a height from 50 to 65 meters. Dense foliage and dark green dominate the forest (Figure 1). It is supported on buttresses provided but sometimes very big. Its bipinnate leaves are composed of tiny leaflets suggestive of a fern [14].

* Therapeutic use of Piptadeniastrum africanum

It is used in the treatment of infections during circumcision. It is also used against childhood diseases; toothache and superinfections of the skin [14].

\subsection{Extraction yield}

We extracted $6.40 \mathrm{~g}$ of $70 \%$ ethanol extract from $10 \mathrm{~g}$ of total aqueous extract, ie an extraction yield of the stem bark of Piptadeniastrum africanum of $64 \%$.

\subsection{Sterility test}

The sterility tests of the $70 \%$ ethanol extract allowed to check the sterility of the extract to be tested. The $70 \%$ ethanolic extract of Piptadeniastrum africanum showed no signs of contamination after three readings separated with 24 hours of incubation.

\subsection{Antibacterial testing}

After 24 hours of incubation at $37{ }^{\circ} \mathrm{C}$., the increasing concentrations of the $70 \%$ ethanol extract caused a gradual decrease in bacterial growth and a dose dependent on the turbidity of the culture medium and that for each bacterial strain studied (Figure 2). The values of the antibacterial parameters 


\begin{tabular}{l|lr|ll|ll} 
& ISRA (India) & $=\mathbf{1 . 3 4 4}$ & SIS (USA) & $=\mathbf{0 . 9 1 2}$ & ICV (Poland) & $=\mathbf{6 . 6 3 0}$ \\
Impact Factor: & ISI (Dubai, UAE) $=\mathbf{0 . 8 2 9}$ & PUH (Russia) $=\mathbf{0 . 2 0 7}$ & PIF (India) & $=\mathbf{1 . 9 4 0}$ \\
& GIF (Australia) & $=\mathbf{0 . 5 6 4}$ & ESJI (KZ) & $=4.102$ & IBI (India) & $\mathbf{4 . 2 6 0}$ \\
& JIF & $=\mathbf{1 . 5 0 0}$ & SJIF (Morocco) & $\mathbf{2 . 0 3 1}$ & & \\
\hline
\end{tabular}

obtained for each bacterial strain are given in Table

1 .

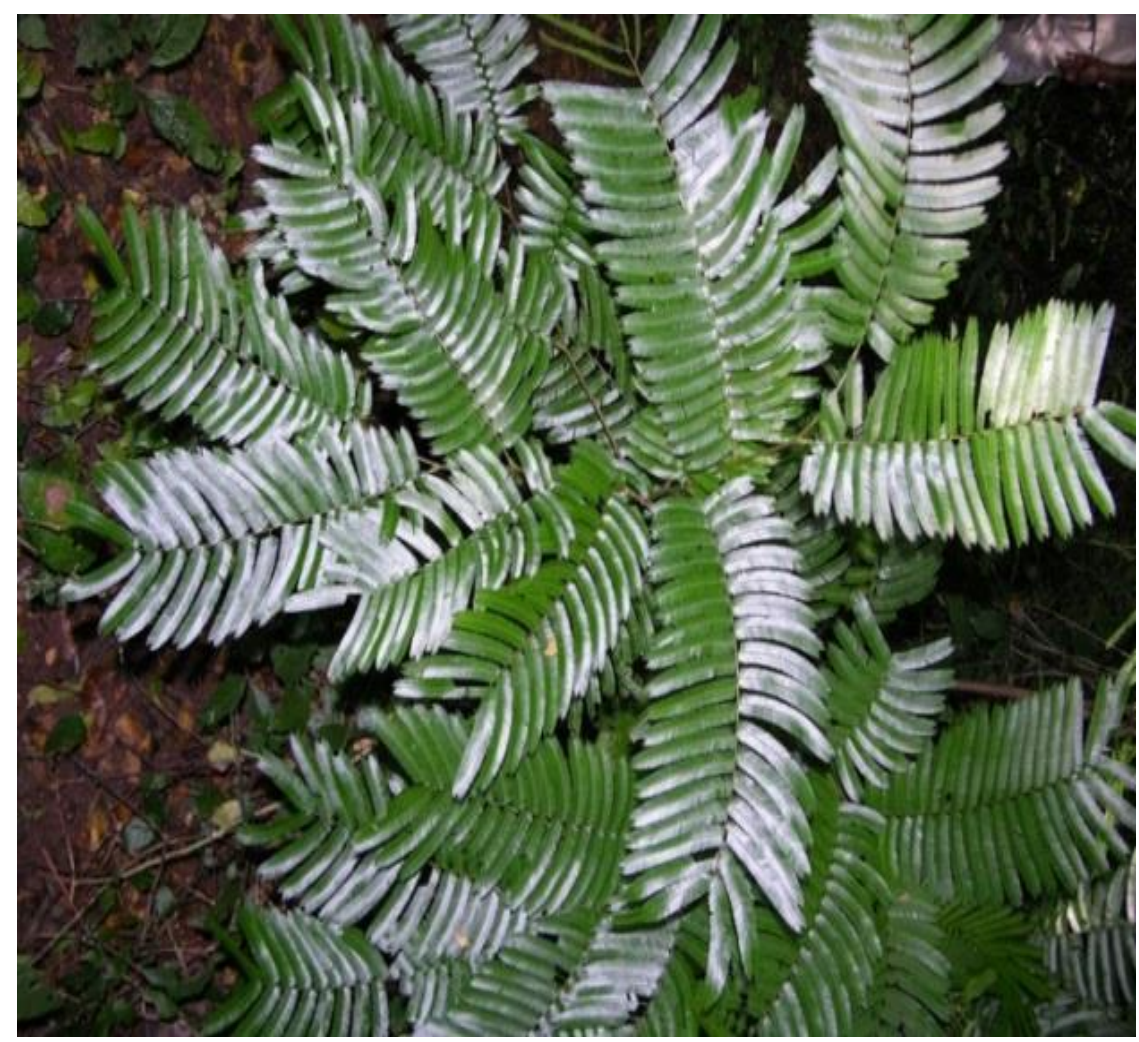

Figure 1 - Leafy twigs of Piptadeniastrum africanum
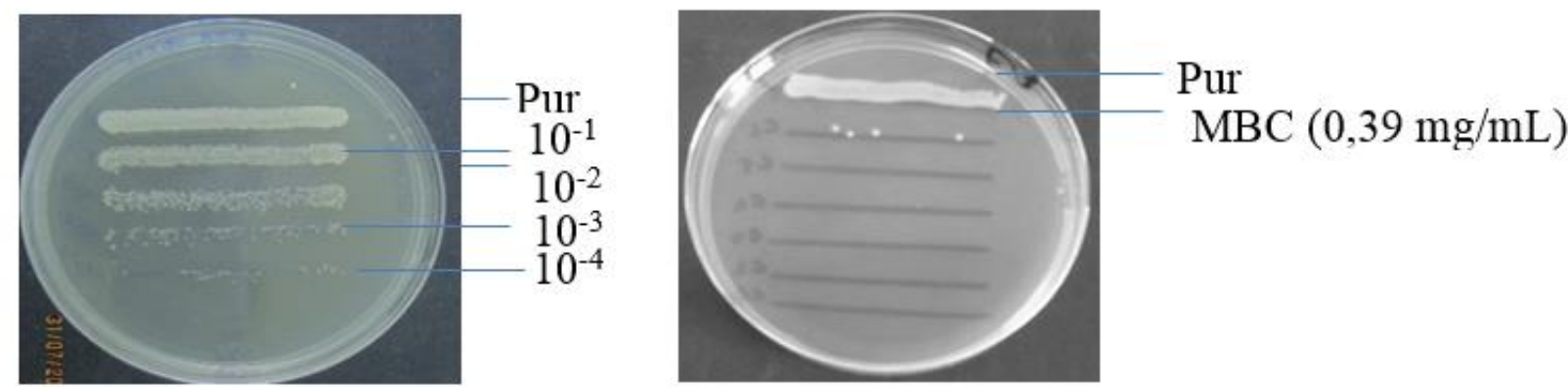

Figure 2 - MBC of the ethanolic extract of Piptadeniastrum africanum on S. aureus 1541C/14

Table 1

Values of the antibacterial parameters of the $70 \%$ ethanolic extract of Piptadeniastrum africanum on the bacterial strains isolated from the urine

\begin{tabular}{|c|c|c|c|c|l|}
\hline $\begin{array}{l}\text { Bacterial } \\
\text { strains }\end{array}$ & Code & $\begin{array}{c}\text { MIC } \\
(\mathrm{mg} / \mathrm{mL})\end{array}$ & $\begin{array}{c}\mathrm{CMB} \\
(\mathrm{mg} / \mathrm{mL})\end{array}$ & MBC/MIC & Activity \\
\hline S.aureus & ATCC & 0,09 & 0,19 & 2,11 & Bactericidal \\
\hline S.aureus & $408 \mathrm{C} / 14$ & 0,04 & 0,09 & 2,25 & Bactericidal \\
\hline S.aureus & $438 \mathrm{UB} / 15$ & 0,09 & 0,09 & 1 & Bactericidal \\
\hline S.aureus & $310 \mathrm{CA} / 15$ & 0,09 & 0,19 & 2,11 & Bactericidal \\
\hline S.aureus & $1541 \mathrm{C} / 14$ & 0,39 & 0,78 & 2 & Bactericidal \\
\hline S.aureus & $446 \mathrm{C} / 14$ & 0,09 & 0,19 & 2,11 & Bactericidal \\
\hline
\end{tabular}

MIC : Minimal Inhibitory Concentration ; MBC : Minimum Bactericidal Concentration

ISPC Generalization of scientific results,

Philadelphia, USA 


\begin{tabular}{|c|c|c|c|c|c|c|}
\hline Impact Factor: & $\begin{array}{l}\text { ISRA (India) } \\
\text { ISI (Dubai, UAE } \\
\text { GIF (Australia) } \\
\text { JIF }\end{array}$ & $\begin{array}{l}=1.344 \\
=0.829 \\
=0.564 \\
=1.500\end{array}$ & $\begin{array}{l}\text { SIS (USA) } \\
\text { PИНЦ (Russia) } \\
\text { ESJI (KZ) } \\
\text { SJIF (Morocco) }\end{array}$ & $\begin{array}{l}=0.912 \\
=0.207 \\
=4.102 \\
=\mathbf{2 . 0 3 1}\end{array}$ & $\begin{array}{l}\text { ICV (Poland) } \\
\text { PIF (India) } \\
\text { IBI (India) }\end{array}$ & $\begin{array}{l}=6.630 \\
=1.940 \\
=4.260\end{array}$ \\
\hline
\end{tabular}

\section{DISCUSSION}

The $70 \%$ ethanolic extract gave a good extraction yield, ie $64 \%$. It could be a good extraction solvent for the active principle of the stem bark of Piptadeniastrum africanum. Tests of the 70 $\%$ ethanolic extract of the stem bark of Piptadeniastrum africanum in agar medium showed, as compared to the growth controls, a decreasing variation in the turbidity of the tubes as the concentration of the extract increases. This shows that this extract exhibits antibacterial activity by inhibiting the in vitro growth of strains of Staphylococcus aureus according to a dose-response relationship. All the tested bacterial strains showed different sensitivities to the $70 \%$ ethanolic extract of the stem bark of Piptadeniastrum africanum. Thus, S. aureus $408 \mathrm{C} / 14$ is the most sensitive with a MIC of $0.04 \mathrm{mg} / \mathrm{mL}$. Comparison of the activity of the $70 \%$ ethanolic extract of the stem bark of Piptadeniastrum africanum on the basis of the MBC relative to the strains of infections and reference shows that the $70 \%$ ethanolic extract is twice as active on S aureus 408C / 14 and S. aureus 412YO / 15 resistant to methicillin. We deduce that the $70 \%$ ethanol extract exerts different inhibitory actions on the tested bacterial strains at different concentrations. Our results are in agreement with that of [14] which showed that Piptadeniastrum africanum had a bactericidal effect on $\mathrm{S}$. aureus. The table of values of the antibacterial parameters also shows the different activities of the $70 \%$ ethanolic extract of the stem bark of Piptadeniastrum africanum on the different strains of Staphylococcus aureus. The activity ratios (MBC / MIC) are less than 4. According to [15], this fraction has a bactericidal activity with regard to the tested germs. Indeed, there are differences in the solubilizing capacity and the extraction of the solvents, with regard to the phytomolecules. According to [16], during the liquid-liquid extraction, the phytomolecules are distributed between the solvents according to their polarity and their solubility. We could say that the antibacterial substances contained in the stem bark of Piptadeniastrum africanum are more soluble in ethanol than in water. Ethanol would better then concentrate the active principle. The work of [17] have shown that the stem bark of Piptadeniastrum africanum contains, among others things, tannins, saponins which possess antibacterial properties. The presence of these chemical compounds could explain its activity on the strains of studied Staphylococcus aureus. All these results provide a scientific basis for the traditional use of this plant, especially in the treatment of wounds, suppurative collectors and urinary tract infections.

\section{CONCLUSION}

Our study showed that the $70 \%$ ethanolic extract of the stem bark of Piptadeniastrum africanum has antibacterial activity on strains isolated from the urine. The extract of the stem bark of Piptadeniastrum africanum could therefore be a less costly alternative for the treatment of urinary tract infections.

\section{References:}

1. Mwambete K. D (2009) The in vitro antimicrobial activity of fruit and leaf crude extracts of Momordica charantia: a tanzania medicinal plant, Afr. Health Sci. 9 (1), 34-39.

2. Mada S. B., Garba A., Mohammed H. A., Muhammad A., Olagunju A., Muhammad A. B (2013) Antimicrobial activity and phytochemical screening of aqueous and ethanol extracts of Momordica charantia L. leaves. J. Med. Plants Res. 7(10), 579-586.

3. Maghrani M., Zeggwagh N., Michel J., Eddoules M (2005) Antihypertensive effect of Lepidium sativum $\mathrm{L}$. in spontaeneously hypertension rats, Journal of Ethnopharmacology, 100 (102) :193 - 197.

4. Biswas B., Rogers K., McLaughlin F., Daniels D., Yadav A (2013) Antimicrobial Activities of
Leaf Extracts of Guava (Psidium guajava L.) on Two Gram-Negative and Gram-Positive Bacteria. International Journal of Microbiology, $2013: 1-7$.

5. Cunningham A.B (1993) African medicinal plants. Setting priorities at the interface between conservation and primary healthcare. Paris, UNESCO (People and Plant Working), $1 \mathrm{p}$.

6. Zirihi G.N., Kra A.M., Guédé-Guina F (2003) Evaluation de l'activité antifongique de Microglossa pyrifolia (Larmarck) O. kuntze (Asteraceae) " pymi " sur la croissance in vitro de Candida albicans. Revue de Médecine et de Pharmacopées Africaines, 17 : 11-19.

7. Zirihi G.N., Kra A., Dadié E.T (2007) Etude botanique et évaluation des activités 


\begin{tabular}{l|lr|ll|ll} 
& ISRA (India) & $=\mathbf{1 . 3 4 4}$ & SIS (USA) & $=\mathbf{0 . 9 1 2}$ & ICV (Poland) & $=\mathbf{6 . 6 3 0}$ \\
Impact Factor: & ISI (Dubai, UAE) $=\mathbf{0 . 8 2 9}$ & PUHЦ (Russia) $=\mathbf{0 . 2 0 7}$ & PIF (India) & $=\mathbf{1 . 9 4 0}$ \\
& GIF (Australia) & $\mathbf{0 . 5 6 4}$ & ESJI (KZ) & $=4.102$ & IBI (India) & $=\mathbf{4 . 2 6 0}$ \\
& JIF & $=\mathbf{1 . 5 0 0}$ & SJIF (Morocco) & $=\mathbf{2 . 0 3 1}$ & & \\
\hline
\end{tabular}

antifongiques de Mitracarpus villosus (MV) (Rubiaceae) et Spermacoce verticillota (SV) (Rubiaceae) sur la croissance in vitro de $A$. fumigatus. Revue de Médecine et de Pharmacopées Africaines, 20 : 9-17.

8. Guessennd K.N (2005) Détermination de l'activité antibactérienne des substances naturelles issues des plantes de la pharmacopée de Côte d'Ivoire. Fiche technique $\mathrm{N}^{\circ} 2$, Institut Pasteur de Côte d'Ivoire, Abidjan (Côte d'Ivoire), $18 \mathrm{p}$

9. Dosso M., Faye-Kette H (2001) Savoir lire et interpréter un antibiogramme. INFAS/CHU de Treichville. Abidjan (Côte d'Ivoire), 35 p.

10. Koné W.M., Kamanzi A.K., Terreaux C., Hostettmann K., Traore D., Dosso M (2004) Traditional medicine in North Côte-d'Ivoire: screening of 50 medicinal plants for antibacterial activity. Journal of Ethnopharmacology, 93: 43-49.

11. Wojciechowski M.F., Lavin M., Sanderson M.J (2004) A phylogeny of Legumes (Leguminosae) based on analysis of the plastid MATK gene resolves many well-supported subclades within the family. American Journal of Botany; 11: 1846-2004.

12. APG III (2009) The Angiosperm Phylogeny Group, «An update of the Angiosperm
Phylogeny Group classification for the orders and families of flowering plants : APG III », Botanical Journal of the Linnean Society, 161(2) : 105-121.

13. Bruneton, J (1999) Pharmacognosie, phytochimie, plantes médicinales. In: Technique et Documentation Lavoisier, Paris, pp. 418-419.

14. Obame E.L.C (2009) Etude phytochimique, activités antimicrobiennes et antioxydantes de quelques plantes aromatiques et médicinales africaines. Thèse de doctorat unique en Biochimie-Microbiologie, Université de Ouagadougou, $277 \mathrm{p}$.

15. Marmonier A. A (1990) Introduction aux techniques d'étude des antibiotiques. In Bactériologie Médicale, Techniques Usuelles. Paris, France, p 227-236.

16. Cowan M.M (1999) Plant products as antimicrobial agents. Clinical Microbial Review, 12: 564-582.

17. Onanga M., Ekouya E., Ouabonzi A. \& Itoua C.B (1997) Etudes ethnobotanique, pharmacologique et chimique des plantes utilisées dans le traitement des dermatoses MWANDZA. Pharmacopée et médecine traditionnelle africaine, $9: 85-93$. 